ISSN 1112-9867

Available online at

http://www.jfas.info

\title{
THE EFFECT OF THE NATURAL RAW BARITE AND THE DOLOMITE MATERIAL ON BORATE GLASS FORMATION
}

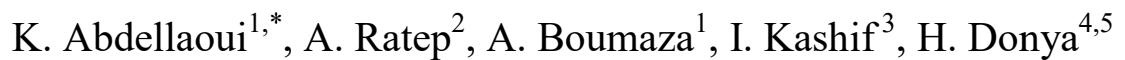

${ }^{1}$ Structural Properties and Interatomic Interactions Laboratory (LASPI ${ }^{2}$ A), Faculty of Science and Technology, University of Abbes Laghrour, Khenchela 40000, Algeria

${ }^{2}$ Physics Department, Faculty of Girls, Aïn Shams University, Cairo, Egypt

${ }^{3}$ Physics department, faculty of science, Al-Azhar University, Nasr city, Cairo, Egypt

${ }^{4}$ Physics Department, Faculty of Science, Menoufia University, Shebin El-Koom, Egypt

${ }^{5}$ Physics Department, Faculty of Science, King Abdulaziz University, Jeddah 21589, Saudi

Arabia

Received: 18 August 2017 / Accepted: 26 December 2017 / Published online: 01 January 2018

\begin{abstract}
The Barite mineral from Ain Mimoun (khenchela-Algeria) and the Dolomie mineral from the Jebel Taioualet (Oum El Bouaghi-Algeria), are used as raw materials to form glass. Glasses in the system $70 \mathrm{H}_{3} \mathrm{BO}_{3}+\mathrm{x} \mathrm{BaSO}_{4}\{$ Barite $\}+(30-\mathrm{x}) \mathrm{CaMg}\left(\mathrm{CO}_{3}\right)_{2}\{$ Dolomie $\}(0 \leq \mathrm{x} \leq 15 \mathrm{~mol} \%)$, have been prepared by the melt quenching technique. Glasses have been investigated by X-ray diffraction, infrared and optical absorption in addition tothe differential thermal analysis (DTA). In FTIR spectroscopy, the fundamental stretching and bending vibrations are observed in the infrared region for $\mathrm{BO}_{3}, \mathrm{BO}_{4}, \mathrm{M}-\mathrm{O}(\mathrm{M}=$ metal $), \mathrm{OH}$ and $\mathrm{SO}_{4}$. The thermal decomposition behaviors determined by means of the differential thermal analysis (DTA). The results proved that, the density, the molar volume and $\mathrm{BO}_{4} /$ total $\mathrm{BO}$ groups ratio of glasses increase with the increasing $\mathrm{BaO}$ concentration, and the UV cut off shift to higher wavelength, while the glass transition temperature and the optical band gap decrease with the augmentationof $\mathrm{BaO}$ concentration.
\end{abstract}

Keywords: Glasses, Barite, Dolomie, FTIR spectroscopy, UV-spectroscopy, differential thermal analysis DTA.

Author Correspondence, e-mail: maher2009@hotmail.fr

doi: http://dx.doi.org/10.4314/jfas.v10i1.21 


\section{INTRODUCTION}

Many studies were carried out to elucidate the presence of different structural units in various borate glasses. Borate rich glasses containing heavy metal oxides have special attention due to their possible applications as laser hosts, lamp phosphors and other photonic devices [1, 2]. $\mathrm{BaO}$ glasses will be a new possibility for a lead-free radiation protecting glass with nontoxicity to our environment. $\mathrm{BaO}$ may be suitable for use as appropriate energy such as $\mathrm{x}$-ray or lower energy level. S. Kaewjaeng et al. [3]. Alkali borate glasses containing divalent oxides such as $\mathrm{BaO}$ interested scientists as they can be used as solid-state electrolytes in the fabrication of solid-state batteries and various technical and industrial applications [4-5]. The nonconductor property of borate glasses is transforming to a semiconducting or electronic or ion conducting nature when metal oxides such as alkali and alkaline earth oxides are added to them [6-7-8]. The ratio of NBOs to Bridging oxygens BOs is an important factor determining the physical properties of the glass and of the melt used to produce the glass [9]. In the present paper the structure of $70 \% \mathrm{H}_{3} \mathrm{BO}_{3}+\mathrm{x} \% \mathrm{BaSO}_{4}+(30-\mathrm{x}) \% \mathrm{MgCa}\left(\mathrm{CO}_{3}\right)_{2}$ glasses is investigated with the help of infrared spectra. Since infrared spectroscopy is the very important tool for the study of amorphous materials, we have used this technique to determine the structure of borate glasses containing varying amounts of $\mathrm{Mg}, \mathrm{Ca}, \mathrm{Ba}, \mathrm{M}$ (M: metal) carbonates, sulfates, and oxides. Samples of the glass were prepared. All the chemicals were weighed accurately using an digital balance. The chemicals were melted in porcelain crucible at $1200^{\circ} \mathrm{C}$ in an electrically programmable heated furnace, type- VAF15/10 lenton thermal designs, equipped with an automatic temperature controller. The molten materials quenched in the air and poured at room temperature.

\section{EXPERIMENTAL TECHNIQUES}

\subsection{Samples and Treatments}

Glasses of different compositions in the system $\left[70 \% \mathrm{H}_{3} \mathrm{BO}_{3}+x \% \mathrm{BaSO}_{4}\right.$ (byrite) $+(30-x)$ $\% \mathrm{MgCa}\left(\mathrm{CO}_{3}\right)_{2}$ (dolomite)] where $\mathrm{x}=0,5,10$ and 15 are fabricated by the melt quenching technique. The samples are melted in a porcelain crucible at $1473 \mathrm{~K}$ for $1.5 \mathrm{~h}$ in an electric muffle furnace (LENTON). A pair of copper blocks is used to quench the glass samples. All the chemicals are weighed accurately using an digital balance; the used raw materials are all of chemically pure grade $\left(\mathrm{H}_{3} \mathrm{BO}_{3}\right)$.Dolomite is extracted from the Jebel Taioualet deposit located in the commune of Ouled Hamla (Wilaya of Oum El Boughi) the Algerian SPA operated by a subsidiary of the public group ENOF. This mineral is treated in the Ain 
Mimoun processing unit in the province of Khenchela. The production of barite in Algeria is done by two (2) mining operators: i) the SPA-SOMIBAR subsidiary of ENOF public group, which run two deposits, one of Mizab in the town of Tamza (W. Khenchela) and that of Boucaid (Tissemsilt province) and ii) the private company named SARL SOBAR. In our work we used the barite which is produced in Khenchela.

\subsection{Characterization of Samples}

All the samples are then characterized using both XRD, SEM observations and qualitative analysis, FTIR spectroscopy and UV spectroscopy.

-X-ray diffraction analysisis performed with a PANalytical X'Pert ProMRD diffractometer with CuKa radiation $(\lambda=0.15418 \mathrm{~nm})$. Data are collected with steps of $0.021^{\circ}(2 \theta)$.

-Scanning electron microscope (SEM) images are taken on a field emission scanning microscope (JEOL 7500-F).

- Fourier transformation Infrared spectroscopy (FTIR) IR spectra are obtained using a Perkin-Elmer spectrometer at the resolution of $8 \mathrm{~cm}^{-1}$. Fourier transform infrared (FTIR) technique is used in the transmission mode in the $400-4000 \mathrm{~cm}^{-1}$ range. For each sample, 120 scans are used. After the oxidation, $\sim 100 \mu \mathrm{g}$ of the oxides are scraped. The oxide is then compressed together with $23 \pm 2 \mathrm{mg}$ of $\mathrm{KBr}$ in a cold $150 \mathrm{MPa}$ isostatic press (CIP) in order to obtain a $200-250 \mu \mathrm{m}$ thick pellet. All infrared spectra are reporting absorbance $\left(A=-\log \frac{\mathrm{I}}{\mathrm{I}_{0}}\right)$ as a function of the incident wave numbers.

- Differential thermal analysis (DTA) measurements are taken using a SHIMADZU DTA50 analyzer. The measurements are taken between 25 and $1000{ }^{\circ} \mathrm{C}$ (in the air using $\mathrm{Al} 2 \mathrm{O} 3$ powder as a reference material) at the rate of $30^{\circ} \mathrm{C} / \mathrm{min}$.

-Optical characterization of samples; the transmittance of $70 \% \mathrm{H}_{3} \mathrm{BO}_{3}+x \% \mathrm{BaSO}_{4}+(30-x)$ $\% \mathrm{MgCa}\left(\mathrm{CO}_{3}\right)_{2}$ samples is measured using a Perkin Elmer UV-VIS-NIR Lambda 19 spectrophotometer in the $190-1100 \mathrm{~nm}$ spectral range.

-The density of the glass samples is measured using the Archimedes principle. The measurements are done using a digital balance and toluene as an inert immersion liquid.

\section{RESULTS AND DISCUSSION}

\subsection{SEM and X-Ray analysis}

The morphology, composition and crystal structure of raw materials are studied using scanning electron microscopy (SEM), the energy dispersive X-ray analysis (EDX), X-ray diffraction (XRD) and FTIR. Fig. 1a and Fig. 1b show the SEM observations of the starting 
minerals. Fig. 2a and Fig. $2 \mathrm{~b}$ show the $\mathrm{X}$ images of elements. As shown, the presence of the elements $\mathrm{Ba}, \mathrm{Ca}, \mathrm{Mg}$, and $\mathrm{O}$ is detected.

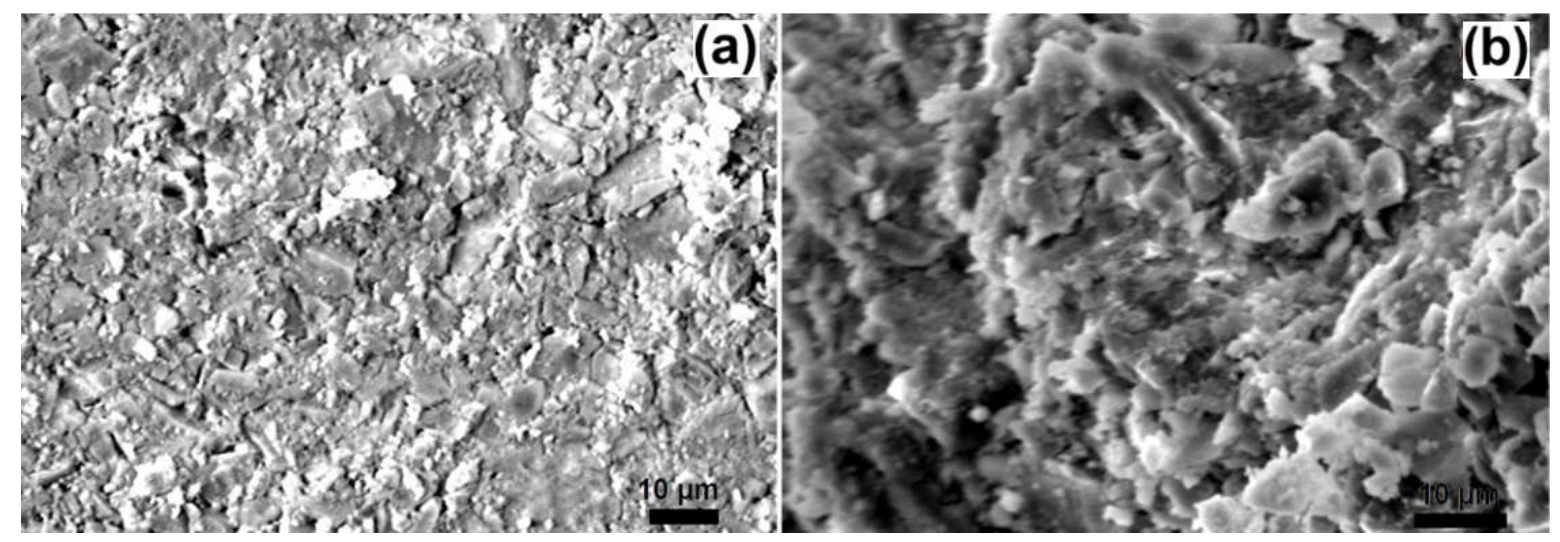

Fig.1. SEM of Barite and Dolomite.
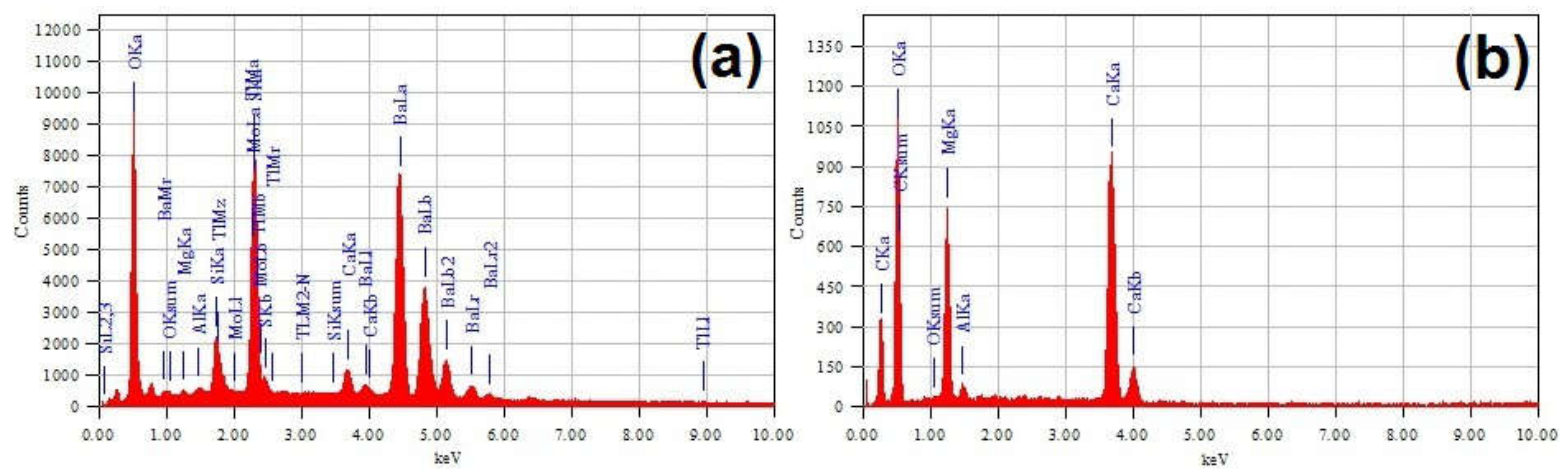

Fig.2. EDX analysis of the Barite (a) and the Dolomite (b).
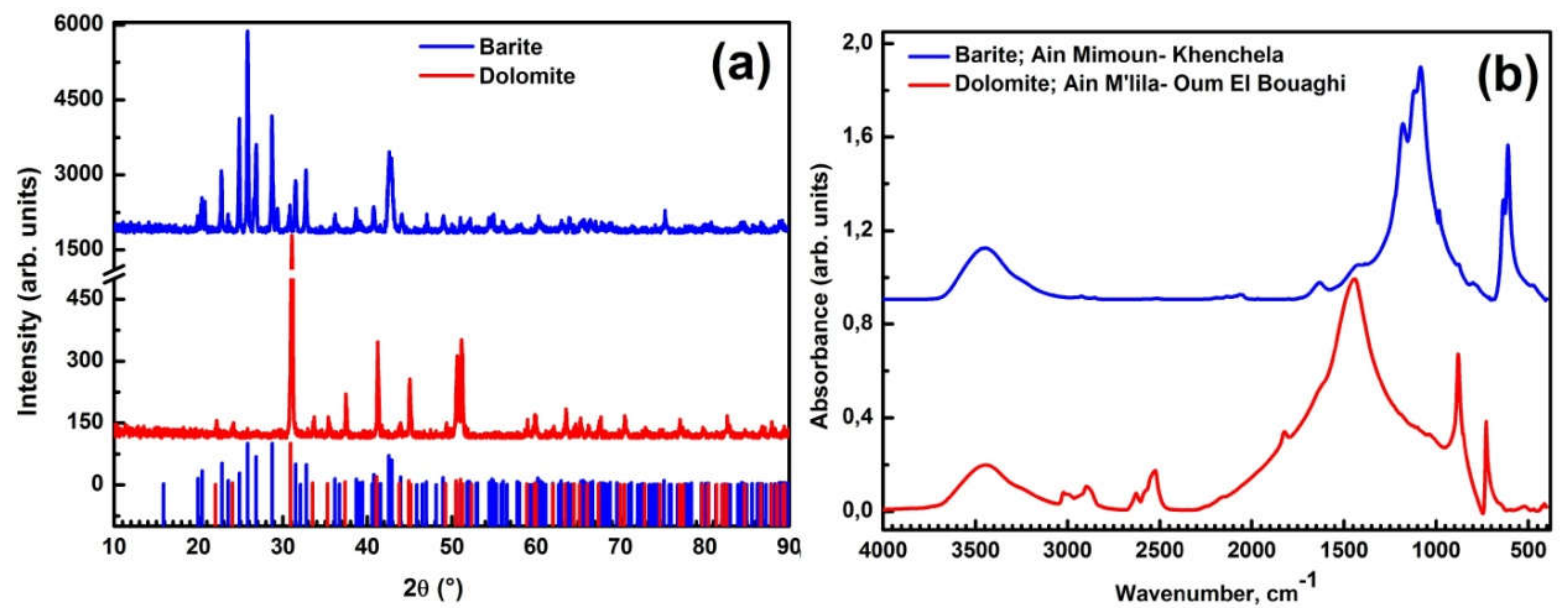

Fig.3. XRD and FTIR spectroscopy of Barite and Dolomite

The XRD patterns of the $\mathrm{BaSO}_{4}$ are depicted in Fig. 3a blue color. In the natural product, several diffraction peaks came along, and all of them could be clearly attributed to the 
prominent peaks such as (210), (102), (211), (112), (020), (401), and (122), respectively of the $\mathrm{BaSO}_{4}$, and it can be well matched with standard JCPDS File No. 72-390. The small peaks between $29^{\circ}$ and $31^{\circ}$ may indicate the presence of small amounts of (Ca, $\mathrm{Si}$ ) complexes whose elements are analyzed by EDX, those compounds in oxidized, sulphidised or hydroxide states.

Also, Fig. 3a red color depicts the X-ray diffraction pattern of the natural dolomite sample at room temperature. XRD pattern attributed to dolomite and matched with standard (JCPDS Files (JCPDS No. 36-426), Figure 3b (blue) shows FTIR spectrum of BaSO4. In figure 3b many bands can be observed at 3445, 2924, 2850, 2061, 1632, 1180, 1116, 1084, 982, 800, $634,610,474 \mathrm{~cm}^{-1}$. FTIR assignments are clarified in table 1 . The results are in agreement with those of the bibliographic data [10-18].

This barite also contains a small amount of silicates and carbonates revealed by the weak bands at 1040, 799, 525, and $462 \mathrm{~cm}^{-1}$ [11].

The carbonates are also revealed at $880-1417 \mathrm{~cm}^{-1}[13]$.

Table 1. Assignment of FTIR bands of $\mathrm{BaSO}_{4}$

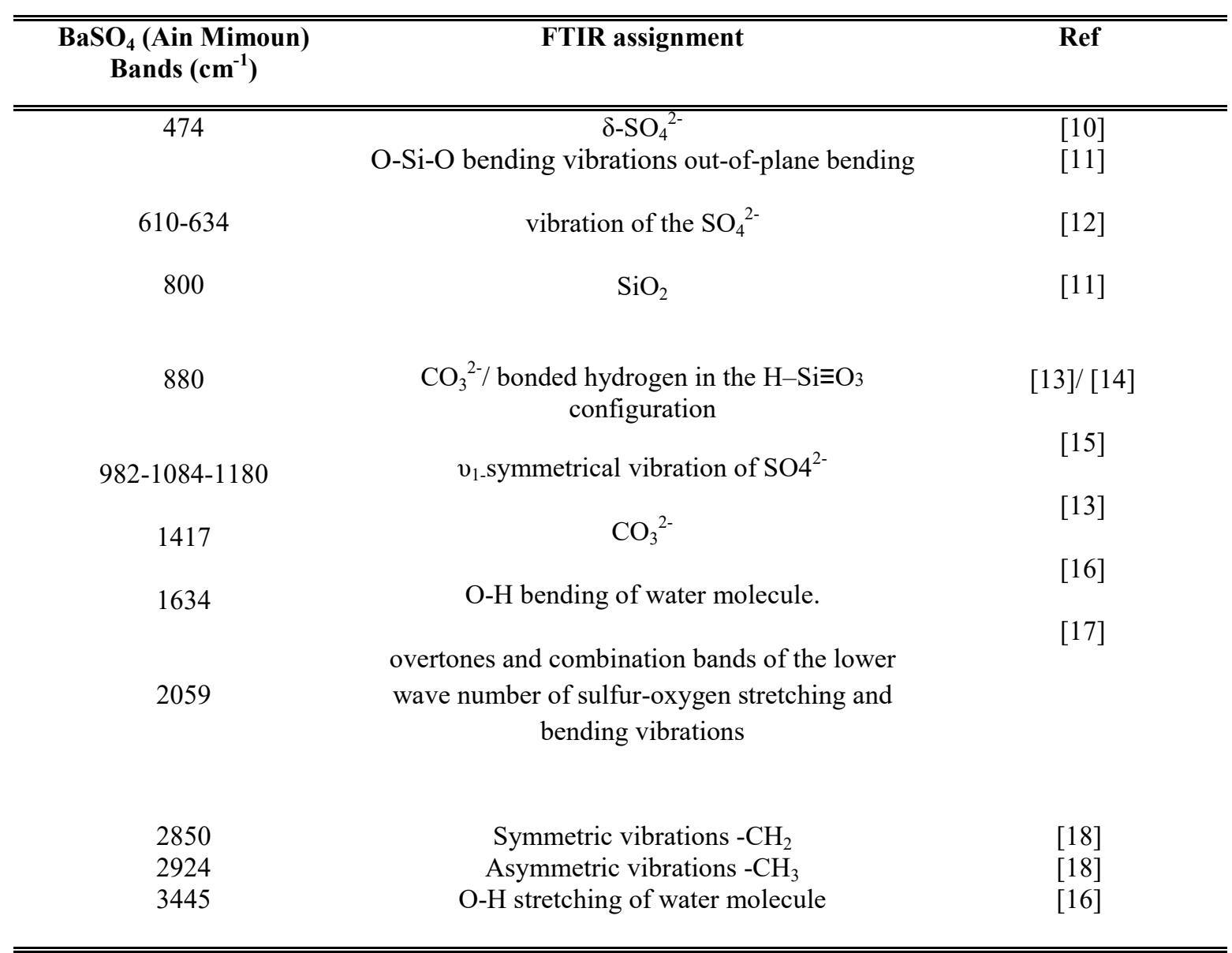


Figure $3 \mathrm{~b}$ (red) shows FTIR spectrum of $\mathrm{MgCa}\left(\mathrm{CO}_{3}\right)_{2}$. We can observe bands at 728,880 , $1438,1618,1636$, and $3440 \mathrm{~cm}-1$. FTIR assignments are clarified in table 2. Also, the results are in agreement with those of the bibliographic data [11-16-18-19]. This dolomite also contains a small amount of silicates revealed by the weak bands at 1040, 799, 525, and 462 $\mathrm{cm}-1[13]$.

Table 2. Assignment of FTIR bands of $\mathrm{CaMg}\left(\mathrm{CO}_{3}\right)_{2}$

\begin{tabular}{ccc}
\hline \hline $\mathbf{C a M g}\left(\mathbf{C O}_{3}\right)_{2}$ & FTIR assignment & Ref \\
\hline \hline- & $v_{1}$ & \\
880 & $v_{2}$ & {$[16]$} \\
1438 & $v_{3}$ & \\
728 & $v_{4}$ & {$[20]$} \\
$1822-2524$ & $v_{1}+v_{4}$ & \\
$2628-2896$ & $2 v_{2}+v_{4}$ & \\
3020 & & {$[21]$} \\
1618 & $\mathrm{C}=\mathrm{O}$ or $\mathrm{C}=\mathrm{C}$ aromatic ring stretching vibrations, \\
1636 & $\mathrm{C}=\mathrm{O}$ stretching mode vibration. & {$[22]$} \\
3440 & $\mathrm{H}_{2} \mathrm{O}$ molecules & {$[16]$} \\
\hline \hline
\end{tabular}

Figure 4 shows the XRD pattern of the investigated glass samples containing raw materials. This figure presents the XRD pattern of the sample containing 0 to $15 \% \mathrm{BaSO}_{4}$ which is typical for all samples (samples are designated G0, G5, G10, and G15, respectively). XRD patterns of all the as-prepared samples show no sharp Bragg's peak, but only a broad diffuse hump around the low angle region (15-35 degrees). This is a clear indication of amorphous nature within the resolution limit of XRD instrument. Furthermore, from figure 4 we can see the sample containing $60 \% \mathrm{~B}_{2} \mathrm{O}_{3}$ and an equal amount of barite and dolomite in crystalline form. May be more energy is needed to form the glass. 

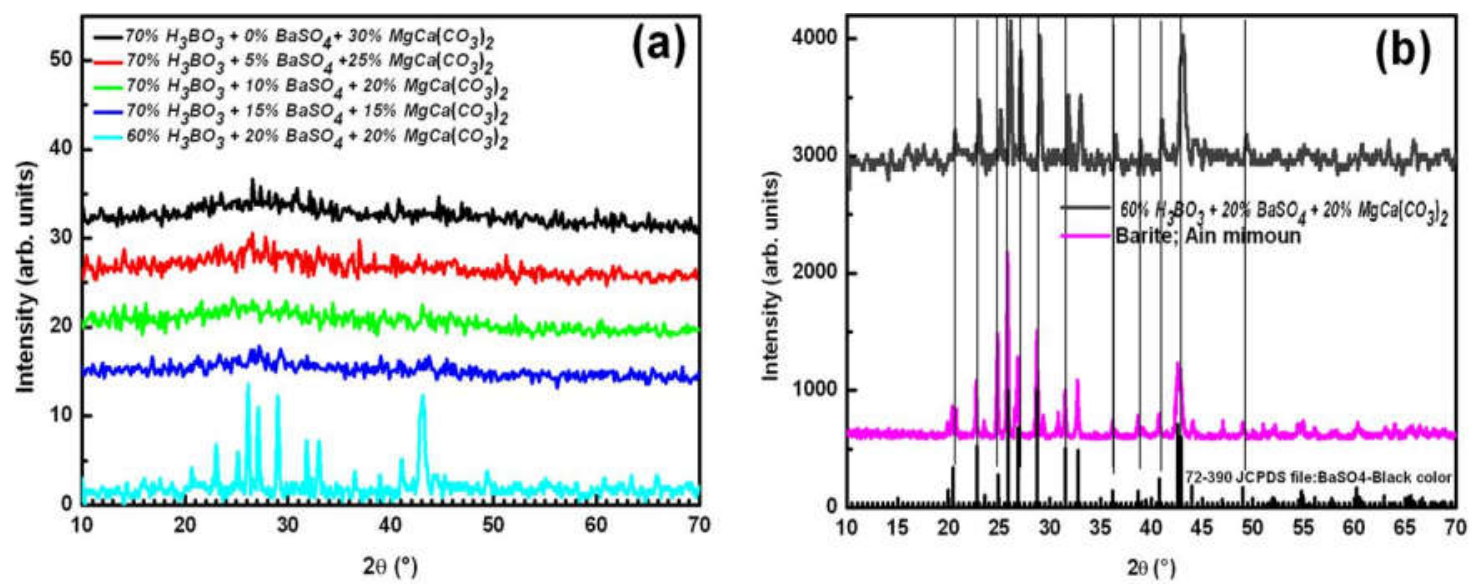

Fig.4. X-ray patterns of all samples

\subsection{Fourier transforms infrared spectroscopy (FTIR) characterizations of the various}

\section{glasses}

Infrared spectroscopy is an important tool for research on the structure and dynamics of materials between order and disorder. IR materials can help to have an idea about the nature of vibrations in a disordered system [23]. The room temperature spectra are obtained using a $\mathrm{KBr}$ pellet technique in the range $400-4000 \mathrm{~cm}^{-1}$. A typical FTIR spectrum of the prepared glass $\left(70 \% \mathrm{H}_{3} \mathrm{BO}_{3}+x \% \mathrm{BaSO}_{4}+(30-x) \% \mathrm{MgCa}\left(\mathrm{CO}_{3}\right)_{2}\right)$ where $\mathrm{x}=0,5,10$ and 15 is shown in Figure 5.
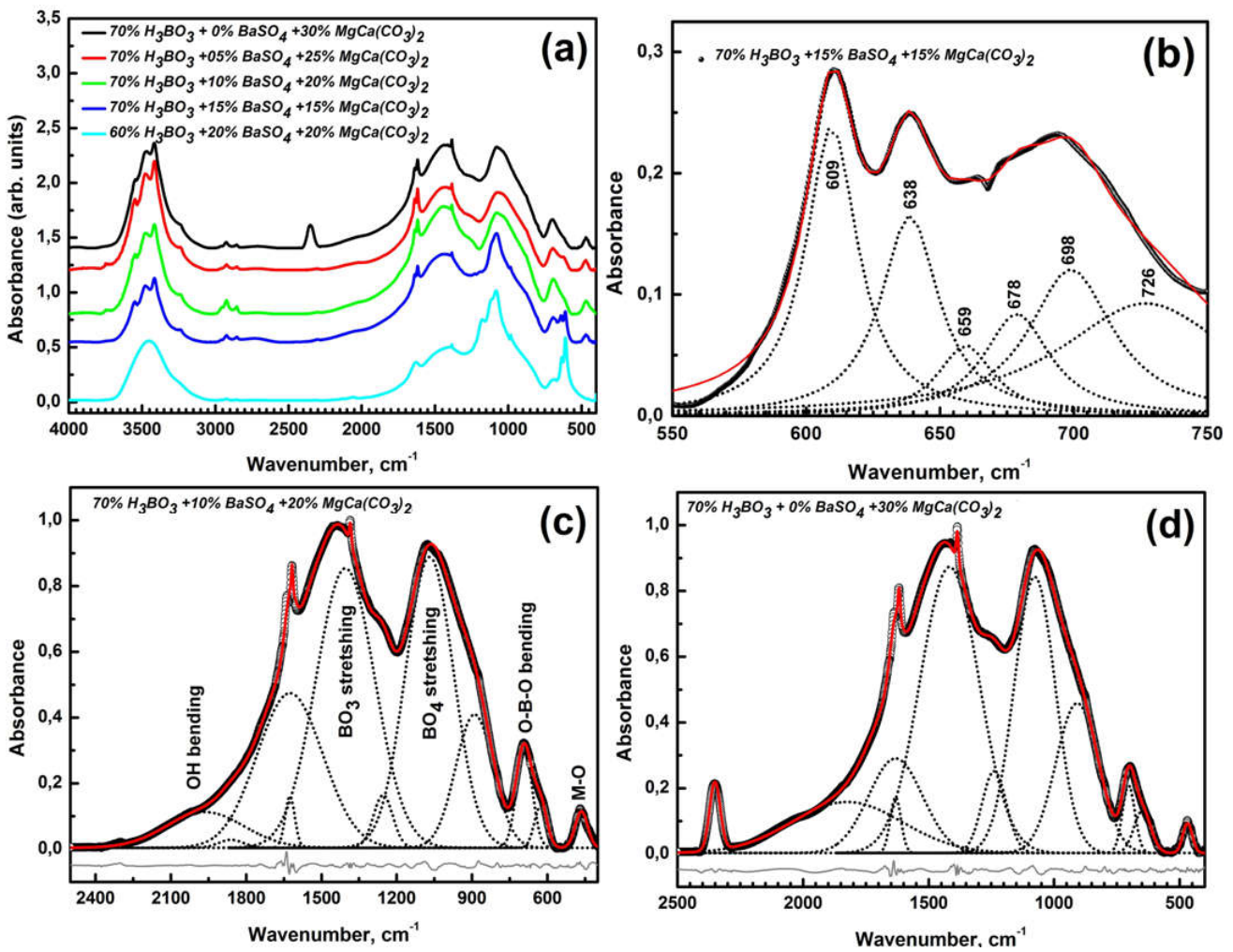

Fig.5. FTIR spectra of the glass samples 
The vibrational modes of the borate network are seen to be mainly active in three infrared spectral regions,

(1) The band at $700 \mathrm{~cm}-1$ and this is due to the bending of $\mathrm{B}-\mathrm{O}-\mathrm{B}$ linkages in the borate networks [24].

(2) The broad band between 800 and $1200 \mathrm{~cm}-1$ and this is due to the B-O bond stretching of the tetrahedral $\mathrm{BO}_{4}$ units (in triborate, tetraborate and pentaborate groups) [29-33].

(3) The broad band which occur between $1200-1600 \mathrm{~cm}-1$ is due to the asymmetric stretching relaxation of the $\mathrm{B}-\mathrm{O}$ band of the trigonal $\mathrm{BO}_{3}$ units [34-38].

The $\mathrm{BO} 3$ and $\mathrm{BO} 4$ groups act as network structural groups

The FTIR analysis of the samples revealed that the network structure of the prepared samples is mainly based on the $\mathrm{BO}_{3}$ and $\mathrm{BO}_{4}$ units. The bands are broad confirming the amorphous nature of the studied glasses.

Table 3. Assignment of FTIR bands of samples glasses

\begin{tabular}{cccccc}
\hline \hline $\begin{array}{c}\text { Sample } \\
\text { G15 }\end{array}$ & $\begin{array}{c}\text { Sample } \\
\text { G10 }\end{array}$ & $\begin{array}{c}\text { Sample } \\
\text { G05 }\end{array}$ & $\begin{array}{c}\text { Sample } \\
\text { G00 }\end{array}$ & FT-IR assignement & Ref \\
\hline \hline 470 & 470 & 468 & 465 & $\begin{array}{l}\text { O-Si-O bending vibrations out-of-plane bending } \\
/ \mathrm{v}_{2}\left(\mathrm{SO}_{4}\right)^{2-} \text { bend/ Asymmetric bending of the } \\
\mathrm{SO}_{4} \text { groups/ B-O-B linkages. }\end{array}$ & {$[10-11-24]$} \\
& & & & &
\end{tabular}

638

698

726

890

873

986

1080

1069

626

691

696

621
648

$v_{4} \mathrm{SO}_{4}$

B-O-B bonds bending vibrations from pentaborate groups,

703

Bending of $\mathrm{B}-\mathrm{O}-\mathrm{B}$ linkages in the borate networks.

$\mathrm{BO}_{3}$ or boroxol groups in glass system

Bending vibrations of $\mathrm{B}-\mathrm{O}$ linkages in borate network

Vibrations Si-O-B bridges

$\mathrm{B}-\mathrm{O}-\mathrm{B}$ linkages bending and isolated $\mathrm{BO}_{3}$ groups

908

Stretching vibrations of $\mathrm{BO}$ bonds in $\mathrm{BO}_{4}$ units from tri, tetra, and penta borate groups

B-O bond stretching of the tetrahedral $\mathrm{BO}_{4}$ units

B-O bonds stretching vibrations in $\left[\mathrm{BO}_{4}\right]$ units from diborate groups

vibrations of structural groups containing $\mathrm{BO}_{4}$ tetrahedra. 


\begin{tabular}{|c|c|c|c|c|c|}
\hline & & & & $\begin{array}{l}\text { transfer of some boron triangle to boron } \\
\text { tetrahedra vibration. }\end{array}$ & [32] \\
\hline 1190 & & & & $\begin{array}{l}\mathrm{B}-\mathrm{O}-\text { asym stretch in } \mathrm{BO}_{3} \text { units from pyro- and } \\
\text { ortho-borate groups }\end{array}$ & [33] \\
\hline \multirow[t]{2}{*}{1230} & 1254 & 1265 & 1238 & $\begin{array}{l}\mathrm{B}-\mathrm{O} \text { stretching vibration of trigonal } \mathrm{BO}_{3} \text { units } \\
\text { in boroxol rings }\end{array}$ & {$[34,35]$} \\
\hline & & & & $\mathrm{B}-\mathrm{O}$ bonds vibrations in $\mathrm{BO}_{3}$ units & {$[36]$} \\
\hline 1384 & $\begin{array}{l}1384 \\
1404\end{array}$ & 1384 & 1385 & $\begin{array}{l}\text { asymmetric stretching relaxation of } \mathrm{B}-\mathrm{O} \text { bonds } \\
\text { of trigonal } \mathrm{BO}_{3} \text { units }\end{array}$ & [37] \\
\hline 1432 & & & 1416 & $\mathrm{~B}-\mathrm{O}$ bonds vibrations in $\mathrm{BO}_{3}$ units & [38] \\
\hline 1618 & 1617 & 1618 & 1617 & $\begin{array}{l}\text { Asymmetric stretching relaxation of } \mathrm{B}-\mathrm{O} \text { bonds } \\
\text { of trigonal } \mathrm{BO}_{3} \text { units }\end{array}$ & [37] \\
\hline \multirow[t]{2}{*}{1638} & 1626 & 1638 & 1632 & Bending modes of $\mathrm{OH}$ groups & [39] \\
\hline & & & 2352 & $\begin{array}{l}\text { Modes of boron-oxygen triangular units }\left(\mathrm{BO}_{3}\right. \\
\left.\text { and } \mathrm{BO}_{2} \mathrm{O}^{-}\right) \\
v 2(\mathrm{H}-\mathrm{O}-\mathrm{H}) \text { bending vibrations of adsorbed } \\
\text { water in the glasses } \\
\text { hydrous species with different hydrogen bond } \\
\text { strengths } \\
\text { Molecular } \mathrm{CO}_{2} / \mathrm{CO}_{2} \text { adsorbed species }\end{array}$ & $\begin{array}{l}{[40]} \\
{[41]} \\
{[42]} \\
{[43,44]}\end{array}$ \\
\hline 2854 & 2854 & 2854 & & $\begin{array}{l}\text { Hydrogen bonding } \\
\text { Symmetric vibrations }-\mathrm{CH}_{2}\end{array}$ & $\begin{array}{l}{[45,46]} \\
{[12]}\end{array}$ \\
\hline 2924 & 2924 & 2924 & 2924 & $\begin{array}{l}\text { Hydrogen bonding } \\
\text { Asymmetric vibrations }-\mathrm{CH}_{3}\end{array}$ & $\begin{array}{l}{[45,46]} \\
{[12]}\end{array}$ \\
\hline $\begin{array}{l}3240- \\
3416- \\
3480-3548\end{array}$ & $\begin{array}{c}3419- \\
3474- \\
3553\end{array}$ & $\begin{array}{c}3416- \\
3480- \\
3548\end{array}$ & $\begin{array}{c}3416- \\
3476- \\
3548\end{array}$ & Molecular water & {$[37,46-44]$} \\
\hline
\end{tabular}

\section{$\mathrm{BO}_{4} /\left(\mathrm{BO}_{4}+\mathrm{BO}_{3}\right)$ ratio}

The structural changes involved by the $\mathrm{BaSO}_{4}$ content addition have been analyzed on the basis of $\mathrm{N}_{4}=\mathrm{BO}_{4} /\left(\mathrm{BO}_{4}+\mathrm{BO}_{3}\right)$ ratio. $\mathrm{BO}_{4}$ and $\mathrm{BO}_{3}$ are calculated as the integral of the absorption signal in the spectral ranges. To quantify the $\mathrm{BaSO}_{4}$ effect on the changes in the relative population of $\mathrm{BO}_{4}$ and $\mathrm{BO}_{3}$ units we have calculated the fraction of four-coordination boron atoms, $\mathrm{N}_{4}$, which is estimated as follows [27, 47, 48]:

From the relative peak areas of $\left\{\mathrm{B} \emptyset_{3}\right.$ and $\left.\mathrm{B} \emptyset_{2} \mathrm{O}-\right\} \quad\left(\mathrm{A}_{3}\right)$ and $\left\{\mathrm{B}_{4}-\right\}\left(\mathrm{A}_{4}\right)$, which were separated by a Gaussian deconvolution, the value of $\mathrm{N}_{4}$ is calculated as $\mathrm{A}_{4} /\left(\mathrm{A}_{4}+\mathrm{A}_{3}\right)$. The quantities $\mathrm{A}_{4}$ and $\mathrm{A}_{3}$ reflect the relative content of tetrahedral $\left(\mathrm{B}_{4}-\right)$ and triangular $\left(\mathrm{B}_{3}\right.$ and $\mathrm{BØ}_{2} \mathrm{O}-$ ) borate species, respectively ( $\varnothing$ representing an oxygen atom bridging two boron atoms). The following method is used in the calculation of the fraction N4 of the fourcoordinated boron atoms in the glass, where [49]. 


$\frac{\text { (concentration of } \mathrm{BO}_{4} \text { tetrahedral) }}{\text { (concentration of } \mathrm{BO}_{4} \text { tetrahedral }+ \text { concentration of } \mathrm{BO}_{3} \text { triangle) }}$
$\mathrm{N}_{4}=\mathrm{A}_{4} /\left(\mathrm{A}_{4}+\mathrm{A}_{3}\right)$

Where $\mathrm{A}_{4}$ and $\mathrm{A}_{3}$ denoted the areas of $\mathrm{BO}_{4}$ units and the areas of component bands and $\mathrm{BO}_{3}$ units. Fraction of four-coordination boron atoms, N4, is plotted in Fig.6. As shown in Fig. 6 the role of $\mathrm{BaSO}_{4}$ as a network modifier on $\mathrm{N}_{4}\left(\mathrm{BO}_{3}\right.$ groups and $\mathrm{BO}_{4}$ groups $)$ is clear. The infrared data revealed the presence of boron atoms in both, three and four coordination states, for all investigated glasses. First of all, it is observed that the $\mathrm{N}_{4}$ values are less than 0.5 for all the investigated samples, showing the predominance of $\mathrm{BO}_{3}$ units in the structure of the studied glasses. The shape of the FT-IR spectra suggests that the controlled addition of $\mathrm{BaSO}_{4}$ generates some rearrangements in the network structure. The value of $\mathrm{N} 4$ increases when $\mathrm{BaSO}_{4}$ increases.

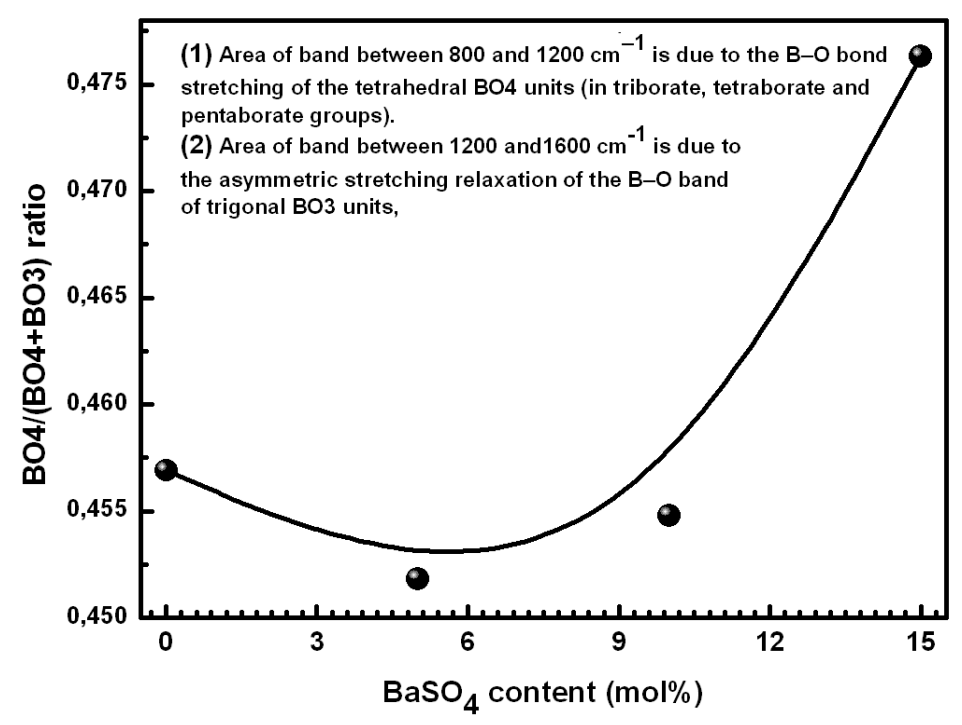

Fig.6. Variation of the Molar Fraction (N4) as functions of $\mathrm{BaSO}_{4}$ content

\subsection{Differential Thermal Analyses}

The samples measured at DTA as viewed in figure 7. Where the glass transition (Tg) is calculated and tabulated in Table 4. 


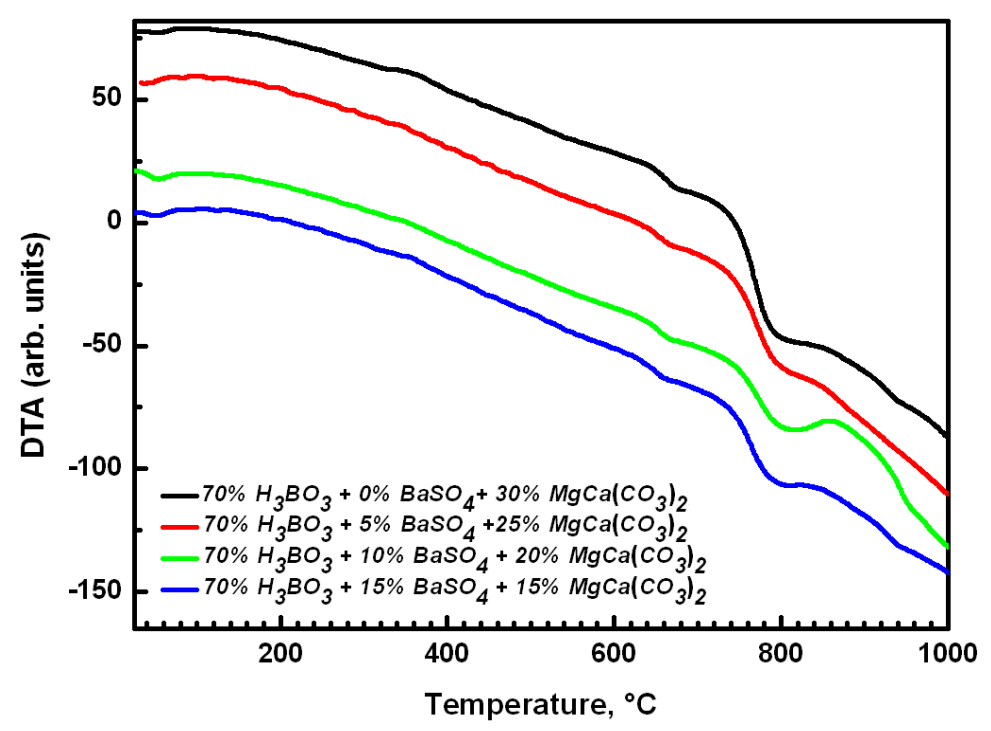

Fig.7. The DTA curves of the system $70 \mathrm{H}_{3} \mathrm{BO}_{3}+x \mathrm{BaSO}_{4}+(30-\mathrm{x}) \mathrm{CaMg}\left(\mathrm{CO}_{3}\right)_{2}$

Table 4. The variations of $\mathrm{Tg}$ and $\mathrm{Tc}$ of samples glasses

\begin{tabular}{cccc}
\hline \hline BaSO $_{4}, \mathbf{~ m o l \%}$ & $\mathbf{T g}\left({ }^{\mathbf{0}} \mathbf{C}\right)$ & $\mathbf{T c}_{\mathbf{1}}\left({ }^{\mathbf{0}} \mathbf{C}\right)$ & $\mathbf{T c}_{\mathbf{2}}\left({ }^{\mathbf{0}} \mathbf{C}\right)$ \\
\hline \hline 0 & 636 & 737.5 & 887.5 \\
5 & 635 & 750 & 860 \\
10 & 633 & 742 & 894 \\
15 & 632 & 741 & 847 \\
\hline \hline
\end{tabular}

From figure 7 and table (4), it can be observed that the values of $\mathrm{Tg}$ decrease slightly with the increase of barite. Decreasing Tg values indicate the formation of non-bridging oxygen $\mathrm{BO}_{3}$ $[50,51]$.

\subsection{UV Spectroscopy (UV) Results}

The optical transmittance spectra of the glass samples recorded in the wavelength region 200 $1100 \mathrm{~nm}$ in the room temperature are shown in figure 8. From these transmittance spectra cutoff wavelength of $\left(\mathrm{BaSO}_{4}\right.$ free $)$ sample is found to be $370 \mathrm{~nm}(3.35 \mathrm{eV})$. With the increasing concentration of barite in the host glass the absorption edge exhibited spectrally red shift found to be $381 \mathrm{~nm}(3.25 \mathrm{eV})$ for the sample containing $5 \mathrm{~mol} \% \mathrm{BaSO}_{4}, 385 \mathrm{~nm}(3.22 \mathrm{eV})$ for the sample containing $10 \mathrm{~mol} \%$, and $400 \mathrm{~nm}(3.09 \mathrm{eV})$ for the sample containing $15 \mathrm{~mol} \%)$ as shown in figure 8 . The observed enormous rise in the cut-off wavelength from 0 to $15 \mathrm{~mol} \%$ $\mathrm{BaSO}_{4}$ indicates the depolymerization of the glass network by the mixed modifier $\mathrm{Ba}, \mathrm{Ca}$ and $\mathrm{Mg}$. No absorption band in the visible region has been detected in the spectrum of all the glass samples with or without $\mathrm{BaSO}_{4}$. 


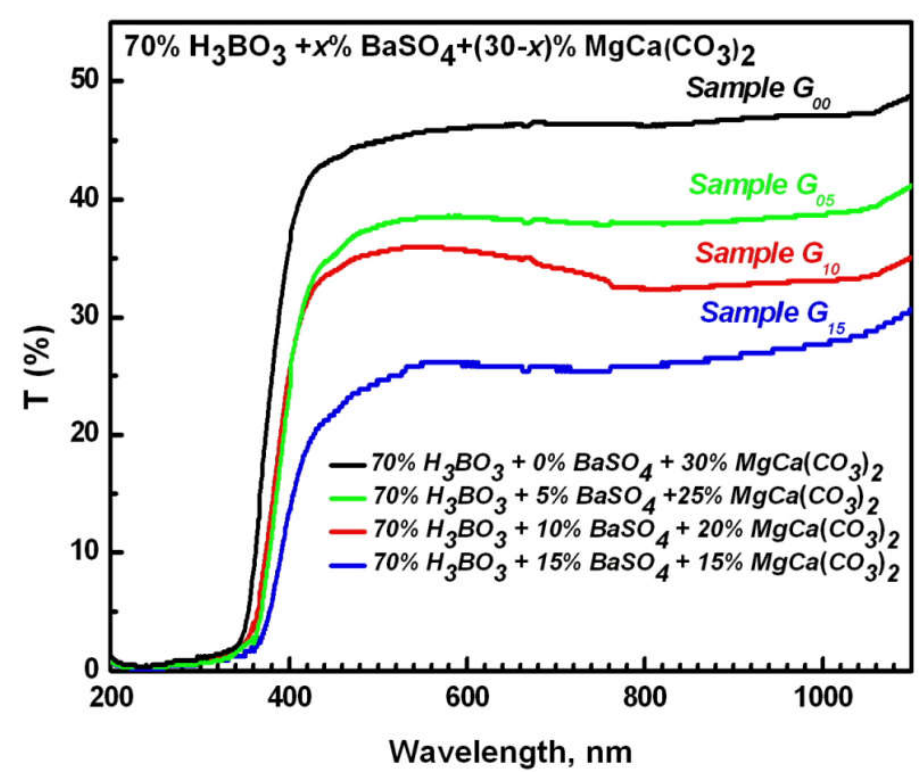

Fig.8. The UV curves of the system $70 \mathrm{H}_{3} \mathrm{BO}_{3}+\mathrm{x} \mathrm{BaSO} 4+(30-\mathrm{x}) \mathrm{CaMg}\left(\mathrm{CO}_{3}\right)_{2}$

The optical band gap (the energy gap between the valence and the conduction bands) of the amorphous system can be obtained from plotting the relation between $(\alpha h v)^{1 / n}(\alpha$ is the absorption coefficient) and the incident photon energy (hv) as given by the equation [52, 53].

$$
\alpha(v)=\frac{\alpha_{0}\left(\mathrm{hv}-\mathrm{E}_{\mathrm{opt}}\right)^{\mathrm{n}}}{\mathrm{h} v}
$$

where $\alpha(v)$ is the absorption coefficient, $\alpha_{0}$ is constant, $n$ is constant depending on the mechanism of electron transition (direct transition or indirect transition) and depending on whether the transition is allowed or forbidden $[54,55]$. The values of $n$ for direct allowed, indirect allowed and direct forbidden transitions are $n=1 / 2,2$, and $3 / 2$, respectively [56]. The value of $E_{\text {opt }}$ and $n$ can be determined by drawing a relation between $(\alpha h v)^{1 / n}$ and ho as shown in figure 9. From figure 9, we can find that the $n$ equal 1/2, which is the trait behavior of the direct allowed transition in all the studied samples. The relation between $\mathrm{E}_{\mathrm{opt}}$ and $\mathrm{BaSO}_{4}$ content is shown in Fig. 10. From Fig. 10, we can see that the optical gap decreases with the increasing $\mathrm{BaSO}_{4}$ content in the glass samples. The decrease in $\mathrm{E}_{\text {opt }}$ with increasing $\mathrm{BaSO}_{4}$ content in the glass samples could be related to the change in the bridging oxygen $\mathrm{BO}$ to the non-bridging oxygen NBO (good agreement with results of infrared), which the bridging oxygen binds energized electrons more firmly than the non-bridging oxygen [56]. In glasses, the negative charge on the NBOs is larger than that on the bridging oxygen. Increasing the iconicity of oxygen ions by converting them from BO to NBO ions decreases the band gap energy $\mathrm{E}_{\mathrm{opt}}$. The concentration of NBOs in the the glass matrix is higher $[57,58]$. This caused 
an increase in the degree of localization of electrons, thereby increasing the donor centers in the glass matrix and decreases of the optical band gap.

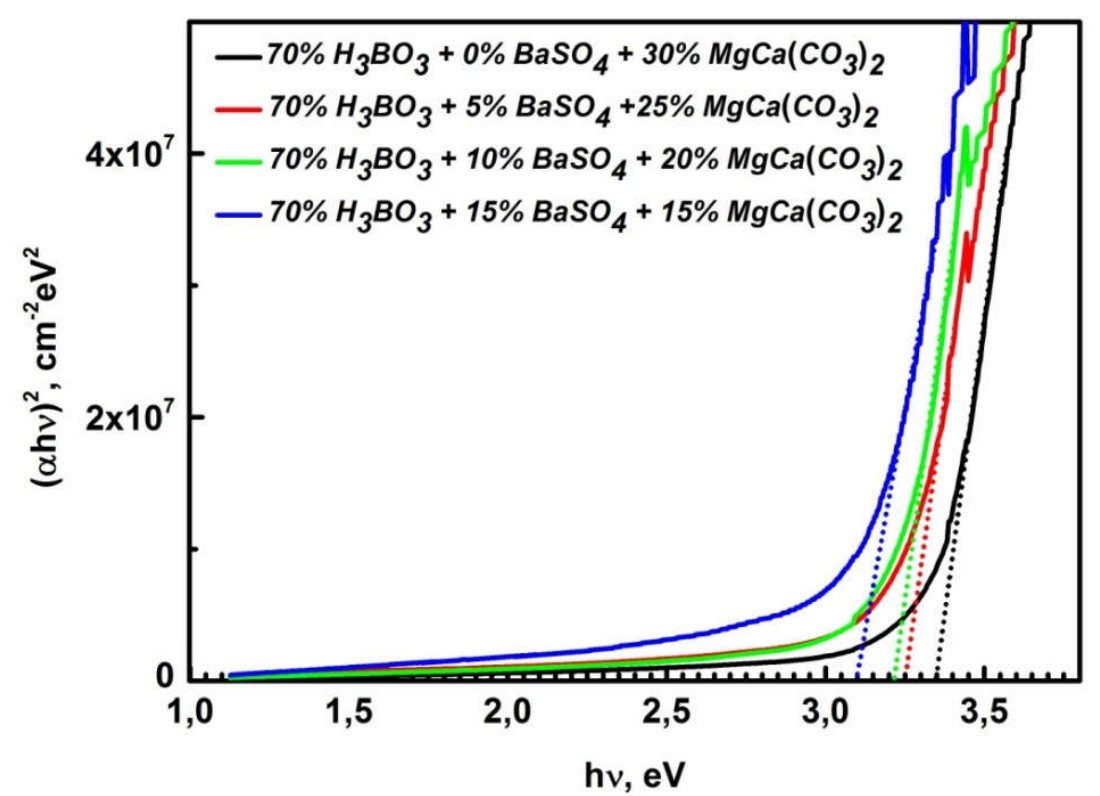

Fig.9.Optical band gap determination

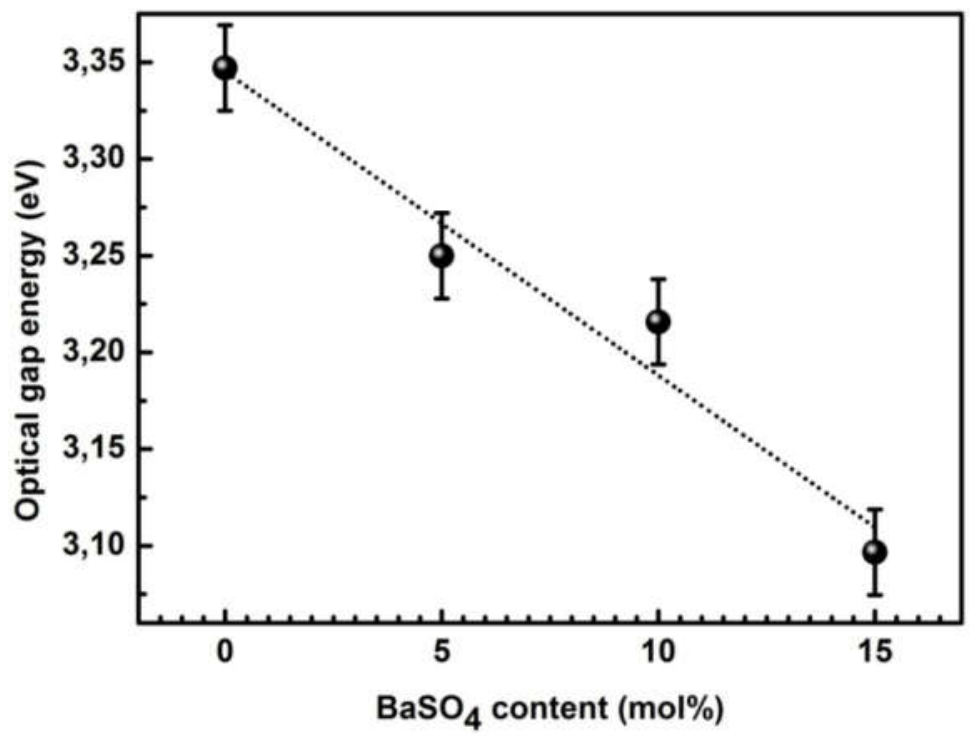

Fig.10. Variation of the optical band gap as a function of $\mathrm{BaSO}_{4}$ content

\subsection{Density Estimation}

Density responds to variations in glass composition sensitively in technological practice. Density of glass, in general, is explained in terms of a competition between the masses and size of the various structural groups present in glass. Accordingly, the density is related to 
how tightly the ions and ionic groups are packed together in the structure [33-59]. Glass density measurements were made at room temperature using the standard "Archimedes principle" with toluene as the immersion fluid of stable density $(0.866 \mathrm{~g} / \mathrm{cm} 3)$. The experimental error was about $\pm 0.003 \mathrm{~g} / \mathrm{cm} 3$. The molar volume $\left[\mathrm{V}_{\mathrm{m}}\right]$ was calculated from molecular weight $[\mathrm{M}]$ and density.

The density is calculated from the formula:

$$
\rho=0.866 \frac{a}{a-b}
$$

Where, $\rho$ is the density of glasses a is the weight of the sample in air, b is the weight of the sample in toluene, and 0.866 is the density of toluene. The density measurement is considered to be a very important tool to detect the structural changes in the glass network. The increase in density is attributed to the change from $\mathrm{BO}_{3}$ group to $\mathrm{BO}_{4}$ group. Theoretically calculated densities were calculated using the relation:

$$
\rho_{\text {calc }}=\sum x_{i} \rho_{i}
$$

Where xi and pi are the molar fraction and density of each component, respectively. The corresponding molar volume $\left(\mathrm{V}_{\text {mcalc }}\right)$ was calculated using the relation:

$$
V_{\text {mcalc }}=\frac{M_{w}}{\rho_{\text {calc }}}
$$

Where $\mathrm{M}_{\mathrm{W}}$ is the total molecular weight of the multi-component glass system, and $\rho$ is the density.
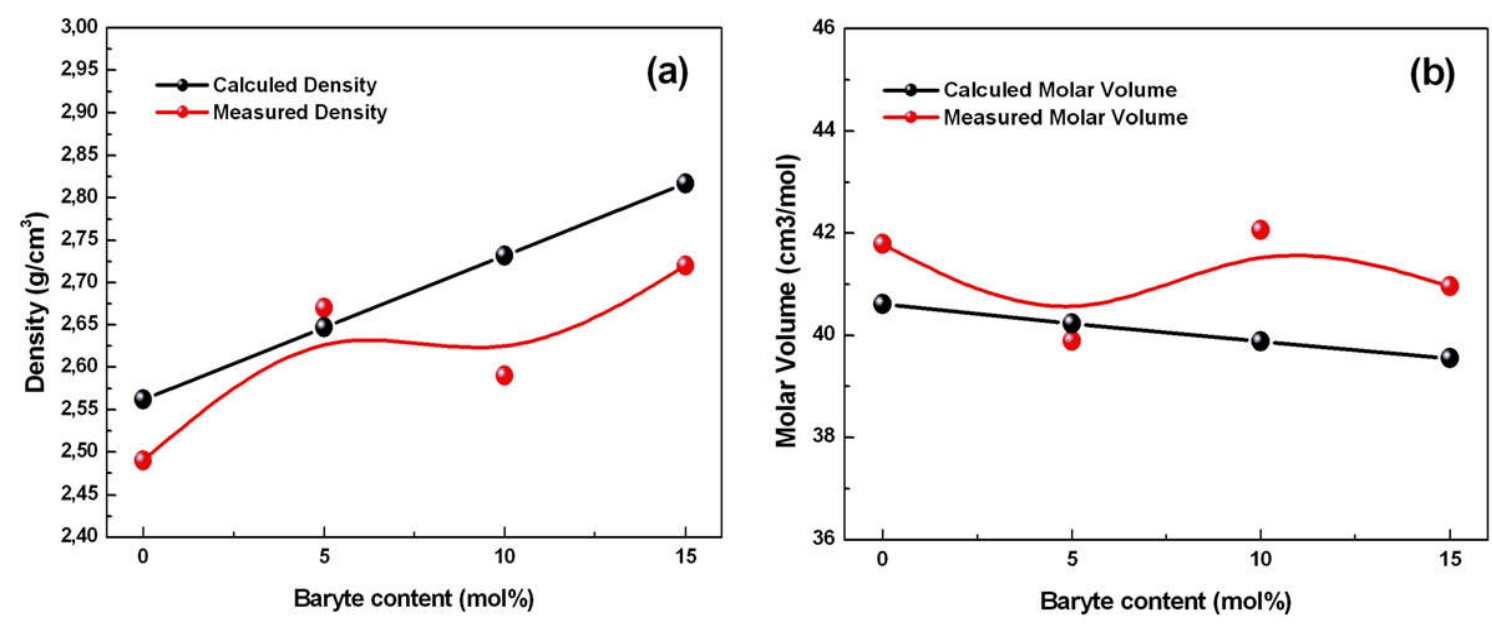

Fig.11. The relation between the density and the molar volume as function of $\mathrm{BaSO}_{4}$ content 
Figure 11.a shows the relation between density and molar as function in $\mathrm{BaSO}_{4}$ content. From figure 11 can be observed that the density increase with the $\mathrm{BaSO}_{4}$ content increase. The density is related to how the modifier and former ions groups are packed together in the structure. Substitution of $\mathrm{Ca}$ and $\mathrm{Mg}$ (having low molecular weight) with $\mathrm{Ba}$ (having high molecular weight) increases the density. Density is directly proportional to the molecular weight, and the increase in $\mathrm{BaSO}_{4}$ content decreases the formation of tetrahedral groups $\left(\mathrm{BO}_{4}\right)$, and increasing the triangle groups $\left(\mathrm{BO}_{3}\right)$ led to the increase in borate non-bridging oxygen (NBO) [59, 60], increasing volume. From Fig. 11-b, it can be observed that the molar volume decreases with the increase in $\mathrm{BaSO}_{4}$ content. The density of the glasses increased while their molar volume values decreases with the increase of barite content in the borate glasses [60].

\section{CONCLUSIONS}

Borate-based glasses containing barite and dolomite minerals have been designed and studied. The analyses by DRX, FTIR spectroscopy, differential thermal analyzes, UV-visible and density analyzes were carried out. The X-ray analyzes demonstrated the amorphous character of the manufactured series. The FTIR analyses have shown that these glasses consist mainly of $\mathrm{BO}_{3}$ and $\mathrm{BO}_{4}$ units. The optical energy gap decreases with the increasing $\mathrm{BaSO}_{4}$ content in the glass samples. The differential thermal analysis (DTA) results show it can be observed that the values of $\mathrm{Tg}$ was estimated to be around $635^{\circ} \mathrm{C}$, with a slight decrease trend. The UV-Visible analyses show that the optical energy gap decreases with the increasing $\mathrm{BaSO}_{4}$ content in the glass samples. From density analysis, it can be observed that the density increases with the $\mathrm{BaSO}_{4}$ content increase and the molar volume decreases.

\section{ACKNOWLEDGMENTS}

This work was supported in part by the National Project Research (PNR) and LASPI ${ }^{2}$ A laboratory of Khenchela University, Algeria.

\section{REFERENCES}

[1] S. Lakshimi Srinivasa Rao, G. Ramadevudu, Md. Shareefuddin, Abdul Hameed, M. Narasimha Chary, M. Lakshmipathi Rao, “Optical properties of alkaline earth borate glasses”, International Journal of Engineering, Science and Technology, 2012, 4, 25-35. 
[2] G. D. Khattak and N. Tabet, "Structural and spectroscopic analyses of copper doped $\mathrm{P}_{2} \mathrm{O}_{5}$ $-\mathrm{ZnO}-\mathrm{K}_{2} \mathrm{O}-\mathrm{Bi}_{2} \mathrm{O}_{3}$ glasses”, Physical Review B, 2005, 72, 104203--14.

[3] S. Kaewjaeng, J. Kaewkhao, P. Limsuwan, U. Maghanemi, “ Effect of BaO on optical, physical and radiation shielding properties of $\mathrm{SiO}_{2}-\mathrm{B}_{2} \mathrm{O}_{3}-\mathrm{Al}_{2} \mathrm{O}_{3}-\mathrm{CaO}-\mathrm{Na}_{2} \mathrm{O}$ glasses system", Procedia Engineering, 2012, 32, 1080-1086.

[4] L. Balachander, G. Ramadevudu, Md. Shareefuddin, R. Sayanna, Y.C. Venudharc, "IR analysis of borate glasses containing three alkali oxides", Science Asia, 2013, 39, 278-283.

[5] R. Ezhil Pavai, M. Indhira, "Study of Elastic Properties of Potassium Borate Glasses Doped With Barium Oxide", International Journal of Innovative Research in Science, Engineering and Technology, 2015, 4, 7244-7252.

[6] N. Nagaraja, T. Sankarappa, M. Prashant Kumar, Santosh Kumar, P. J. Sadashivaiah, "Dielectric relaxation studies in single and mixed alkali doped cobalt-borate glasses", Optoelectronics \& Advanced Materials - Rapid Communications, 2008, 2, 22 - 25.

[7] R. Palani, G. Srinivasan, "Elastic properties of $\mathrm{Ba}^{2+}$ and $\mathrm{Mn}^{2+}$ metal iron doped lithium borate glasses using pulse-echo technique”, Int. J. Rec. Scien. Res., 2012, 3, 992-996.

[8] P. Limkitjaroenporn, J. Kaewkhao, P. Limsuwan, W. Chewpraditkul, "Physical, optical, structural and gamma-ray shielding properties of lead sodium borate glasses", Journal of Physics and Chemistry of Solids, 2011,72 , 245-251.

[9] J. F. Stebbins, P. Zhao, S. Kroeker, "Non-bridging oxygens in borate glasses: characterization by ${ }^{11} \mathrm{~B}$ and ${ }^{17} \mathrm{O}$ MAS and 3QMAS NMR", Solid State Nuclear Magnetic Resonance, 2000, 16, 9-19.

[10] V. G. Vyatchina, L. A. Perelyaeva, M. G. Zuev, I. V. Baklanova, "Structure and Properties of Glasses in the $\mathrm{MgSO}_{4}-\mathrm{Na}_{2} \mathrm{~B}_{4} \mathrm{O}_{7}-\mathrm{KPO}_{3}$ System", Glass Physics and Chemistry, 2009, 35, 580-585.

[11] S. Musić, N. Filipović-Vinceković, L. Sekovanić, “ Precipitation of Amorphous SiO2 Particles and Their Properties", Brazilian Journal of Chemical Engineering, 2011, 28, 89 94.

[12] Y. Shen, C. Li, X. Zhu, A. Xie, L. Qiu, J. Zhu, "Study on the preparation and formation mechanism of barium sulphate nanoparticles modified by different organic acids", J. Chem. Sci., 2007, 119, 319-324.

[13] E. TkalČec, J. Popović, S. Orlić, S. Milardović, H. Ivanković, “ Hydrothermal synthesis and thermal evolution of carbonate-fluorhydroxyapatite scaffold from cuttlefish bones ", Mater. Sci. En.g C Mater. Biol. Appl., 2014, 42, 578-586. 
[14] E. San Andrés, A. del Prado, I. Mártil, and G. González-Díaz, "Bonding configuration and density of defects of $\mathrm{SiO}_{\mathrm{x}} \mathrm{H}_{\mathrm{y}}$ thin films deposited by the electron cyclotron resonance plasma method", Journal of Applied Physics, 2003, 94, 7462-7469.

[15] H. H. Adler, P. F. Kerr, "Variations in Infrared Spectra, Molecular Symmetry and Site Symmetry of Sulfate", The American Mineralogist, 1965, 50, 132-147.

[16] V. Ramaswamy, R. M. Vimalathithan1, V. Ponnusamy, "Synthesis and characterization of BaSO4 nano particles using microemulsion technique", Advances in Applied Science Research, 2010, 1, 197-204.

[17] J. Manam, S. Das, “ Thermally stimulated luminescence studies of undoped, $\mathrm{Cu}$ and $\mathrm{Mn}$ doped $\mathrm{BaSO}_{4}$ compounds”, Indian J. Pure \& Ap. Phy., 2009, 47, 435-438.

[18] S. Sivakumar, P. Soundhirarajan, A. Venkatesan, Chandra Prasad Khatiwada, “ Spectroscopic studies and antibacterial activities of pure and various levels of $\mathrm{Cu}$-doped $\mathrm{BaSO}_{4}$ nanoparticles", Spectrochimica Acta Part A: Molecular and Biomolecular Spectroscopy, 2015, 151, 895-907.

[19] M. D. Lane, "Mid-infrared emission spectroscopy of sulfate and sulfate-bearing minerals", American Mineralogist, 2007, 92, 1-18.

[20] Junfeng Ji, Yun Ge, William Balsam, John E. Damuth, "Rapid identification of dolomite using a Fourier Transform Infrared Spectrophotometer (FTIR): A fast method for identifying Heinrich events in IODP Site U1308”, Marine Geology, 2009, 258, 60-68.

[21] I. Oikonomopoulos, Th. Perraki, N. Tougiannidis, “FTIR study of two different lignite lithotypes from neoceneachlada lignite deposits in new Greece", Bulletin of the Geological Society of Greece, Proceedings of the 12th International Congress. Patras., 2010, 05, 2284 2293.

[22] R. Senthil Kumar, Kumar P. Rajkumar, "Characterization of minerals in air dust particles in the state of Tamilnadu, India through FTIR, XRD and SEM analyses", Infrared Physics \& Technology, 2014, 67, 30-41.

[23] P. Becker, "Thermal and optical properties of glasses of the system $\mathrm{Bi}_{2} \mathrm{O}_{3}-\mathrm{B}_{2} \mathrm{O}_{3}$ ", Crystal Research and Technology. 2003, 38(1), 74-82.

[24] K. Lu, M. K. Mahapatra, "Network structure and thermal stability study of high temperature seal glass”, Journal of Applied Physics, 2008, 104, 074910-074919.

[25] I. Ardelean, V. Timar, "FT-IR and Raman spectroscopic studies on $\mathrm{MnO}-\mathrm{B}_{2} \mathrm{O}_{3}-\mathrm{PbO}-$ $\mathrm{Ag}_{2} \mathrm{O}$ glasses", Journal of Optoelectronics and advanced Materials., 2008, 10, 246-250. 
[26] S. G. Motke, S. P. Yawale, S. S. Yawale, “ Infrared spectra of zinc doped lead borate glasses”, Bull. Mater. Sci., Indian Academy of Sciences , 2002, 25, 75-78.

[27] C. R. Gautam, Avadhesh Kumar Yadav, Arbind Kumar Singh, "A Review on Infrared Spectroscopy of Borate Glasses with Effects of Different Additives”, ISRN Ceramics., 2012, 1-17.

[28] S.Thirumaran, N. Prakash, "Structural characterization of some borate glass specimen by ultrasonic, spectroscopic and SEM studies”, Indian Journal of Pure \& Applied Physics., 2015, 53, 82-92.

[29] L. Balachander, G. Ramadevudu, Md. Shareefuddin, R. Sayanna, Y.C. Venudhar, "IR analysis of borate glasses containing three alkali oxides”, Science Asia, 2013, 39, 278-283.

[30] R. Vijaya Kumar, P. Gayathri Pavani, B. Ramesh, M. Shareefuddin, K. Siva Kumar, "Structural studies of $x \mathrm{xi}_{2} \mathrm{O}-(40-\mathrm{x}) \mathrm{Bi}_{2} \mathrm{O}_{3}-20 \mathrm{CdO}-40 \mathrm{~B}_{2} \mathrm{O}_{3}$ glasses", Optical Materials, 2013, 35, 2267-2274.

[31] K. El-Egili, "Infrared studies of $\mathrm{Na}_{2} \mathrm{O}-\mathrm{B}_{2} \mathrm{O}_{3}-\mathrm{SiO}_{2}$ and $\mathrm{Al}_{2} \mathrm{O}_{3}-\mathrm{Na}_{2} \mathrm{O}_{-}-\mathrm{B}_{2} \mathrm{O}_{3}$ -

$\mathrm{SiO}_{2}$ glasses", Physica B., 2003, 325,340-348.

[32] M. Sanad, I. Kashif, A. A. EL-Sharkawy, A. A. EL-Saghier, H. Farouk, "Infrared study of the effect of heat treatment and irradiation on barium borate glass containing iron", Journal of Materials Science, 1986, 21, 3483-3490.

[33] P. Pascuta, L. Pop, S. Rada, M. Bosca, E. Culea, “The local structure of bismuth borate glasses doped with europium ions evidenced by FT-IR spectroscopy”, J. Mater. Sci.: Mater. Electron. 2008, 19, 424- 428.

[34] M. Toderas, S. Filip, I. Ardelean, “Structural study of the $\mathrm{Fe}_{2} \mathrm{O}_{3}-\mathrm{B}_{2} \mathrm{O}_{3}-\mathrm{BaO}$ glass system by FTIR spectroscopy", Journal of Optoelectronics and Advanced Materials, 2006, 8,1121 1123.

[35] I. Ardelean, F. Ciorcas, M. Peteanu, I. Bratu, V. Ioncu, “ The structural study of $\mathrm{Fe}_{2} \mathrm{O}_{3^{-}}$ $\mathrm{TeO}_{2}-\mathrm{B}_{2} \mathrm{O}_{3}-\mathrm{SrF}_{2}$ glasses by EPR and IR spectroscopies”, Modern. Phys. Lett. B., 2000, 14, $651-653$.

[36] Ioan Ardelean, Simona Cora, “FT-IR, Raman and UV-VIS spectroscopic studies of copper doped $3 \mathrm{Bi}_{2} \mathrm{O}_{3} \mathrm{~B}_{2} \mathrm{O}_{3}$ glass matix”, J Mater Sci: Mater Electron., 2008, 19, 584-588.

[37] C. Gautam, A. K. Singh, A. Madheshiya, "Preparation and Optical Investigations of $\left[\left(\mathrm{Sr}_{1-\mathrm{x}} \mathrm{Bi}_{\mathrm{x}}\right) \mathrm{TiO}_{3}\right]-\left[2 \mathrm{SiO}_{2} \mathrm{~B}_{2} \mathrm{O}_{3}\right]-\left[\mathrm{CeO}_{2}\right]$ Glasses", Advances in Optics, 2014, 1-7. 
[38] I. Ardelean, S. Cora, V. Ioncu, "Structural investigation of $\mathrm{CuO}-\mathrm{Bi}_{2} \mathrm{O}_{3}-\mathrm{B}_{2} \mathrm{O}_{3}$ glasses by FT-IR, Raman and UV-VIS spectroscopies", Journal of Optoelectronics and Advanced Materials, 2006, 8, $1843-1847$.

[39] J. Coelho, C. Freire, N. S. Hussain, “ Structural studies of lead lithium borate glasses doped with silver oxide", Spectrochimica Acta Part A., 2012, 86, 392- 398.

[40] F. H. ElBatal, "Gamma ray interaction with lithium borate glasses containing $\mathrm{WO}_{3}$ ", Indian Journal of Pure \& Applied Physics, 2009, 47, 471- 480.

[41] J. Madejova, "FTIR techniques in clay mineral studies", Vibrational Spectroscopy, 2003, 31, 1-10.

[42] N. Zotov, H. Keppler, "The influence of water on the structure of hydrous sodium tetrasilicate glasses", American Mineralogist, 1998, 83, 823-834.

[43] Alexander Konschak, Hans Keppler, "The speciation of carbon dioxide in silicate melts ”, Contributions to Mineralogy and Petrology 2014, 167, 1-13.

[44] O. Seiferth, K. Wolter, B. Dillmann, G. Klivenyi, H. J. Freund, D. Scarano, A. Zecchina, "IR investigations of $\mathrm{CO}_{2}$ adsorption on chromia surfaces: $\mathrm{Cr}_{2} \mathrm{O}_{3}(0001) / \mathrm{Cr}$ (110) versus polycrystalline $\alpha-\mathrm{Cr}_{2} \mathrm{O}_{3}{ }^{\prime \prime}$, Surface Science, 1999, 421, 176-190.

[45] C. Gautam, A. K. Yadav, V. K. Mishra, K. Vikram, "Synthesis IR and Raman spectroscopic studies of $(\mathrm{Ba}, \mathrm{Sr}) \mathrm{TiO}_{3}$ borosilicate glasses with addition of $\mathrm{La}_{2} \mathrm{O}_{3}$ ", Open Journal of Inorganic Non-metallic Materials, 2012, 2, 47-54.

[46] C. R. Gautam, Avadhesh Kumar Yadav, "Synthesis and Optical Investigations on (Ba, $\mathrm{Sr}) \mathrm{TiO}_{3}$ Borosilicate Glasses Doped with $\mathrm{La}_{2} \mathrm{O}_{3}$ ”, Optics and Photonics Journal, 2013, 3, 1-7.

[47] H. Aboud, H.Wagiran, I. Hossain, R. Hussin, "Infrared Spectra and Energy band gap of Potassium Lithium Borate glass dosimetry", International Journal of Physical Sciences, 2012, 7, 922-926.

[48] P. Pascuta, M. Bosca, S. Rada, M. Culea, I. Bratu, E. Culea, “FTIR spectroscopic study of $\mathrm{Gd}_{2} \mathrm{O}_{3}-\mathrm{Bi}_{2} \mathrm{O}_{3}-\mathrm{B}_{2} \mathrm{O}_{3}$ glasses", Journal of Optoelectronics and advanced Materials, 2008, 10, $2416-2419$.

[49] I. Kashif, A. Ratep, "Role of copper metal or oxide on physical properties of lithium borate glass", Journal of Molecular Structure, 2015, 1102, 1-5.

[50] A. A. Soliman, E. M. Sakr, I. Kashif, "The investigation of the influence of lead oxide on the formation and on the structure of lithium diborate glasses”, Mater. Sci. Eng. B., 2009, $158,30-34$.

[51] I. Kashif, A. A. Soliman, E. M. Sakr, A. Ratep, “ Effects of the addition of transition 
metal ions on some physical properties of lithium niobium borate glasses ", Phys. Chem. Glasses: Eur. J. Glass Sci. Technol. B., 2014, 55, 34-40.

[52] B. Sumalatha, I. Omkaram, T. Rajavardhana Rao, ChLinga Raju, “Alkaline earth zinc borate glasses doped with $\mathrm{Cu}^{2+}$ ions studied by EPR, optical and IR techniques", J. NonCrystalline Solids, 2011, 357, 3143-3152.

[53] R. Stefan, E. Culea, P. Pascuta, "The effect of copper ions addition on structural and optical properties of zinc borate glasses”, J. Non-Crystalline Solids, 2012, 358, 839-846.

[54] N.V.V. Prasad, K. Annapurna, N. Sooraj Hussain, S. Buddhudu, "Spectral analysis of $\mathrm{Ho}^{3+}: \mathrm{TeO}_{2}-\mathrm{B}_{2} \mathrm{O}_{3}-\mathrm{Li}_{2} \mathrm{O}$ glass", Mater. Lett., 2003, 57, 2071-2080.

[55] I. Kashif, A. Ratep, A.M. Sanad, “ Optical properties of lithium lead borate glass containing copper oxide for color filter and absorption glass", Opt Quant. Electron., 2015, 47, 673-684.

[56] V. I. Arbuzov, "Fundamental absorption spectra and elementary electronic excitations in oxide glasses", Glass. Phys. Chem., 1996, 22, 477- 489.

[57] I. Kashif, A. Abd El-ghany, A. Abd El-Maboud, M.A. Elsherbiny, A.M. Sanad, "IR, density and DTA studies the effect of replacing $\mathrm{Pb}_{3} \mathrm{O}_{4}$ by $\mathrm{CuO}$ in pseudo-binary $\mathrm{Li}_{2} \mathrm{~B}_{4} \mathrm{O}_{7}$ $\mathrm{Pb}_{3} \mathrm{O}_{4}$ glass system”, J. Alloys Compd., 2010, 503, 384-388.

[58] I. Kashif, A.Ratep", The effect of copper oxide on structure and physical properties of lithium lead borate glasses”, Applied Physics A., 2015, 120, 1427-1434.

[59] H. Darwish, M. M. Gomaa, "Effect of compositional changes on the structure and properties of alkali-alumino borosilicate glasses", Journal of Materials Science: Materials in Electronics, 2006, 17, 35-42.

[60] U. B. Chanshetti, V. A. Shelke, S. M. Jadhav, S. G. Shankarwar, T. K. Chondhekar, A. G. Shankarwar, V. Sudarsan, M. S. Jogad, "Density and Molar Volume Studies of Phosphate Glasses", Facta Universitatis Series: Physics, Chemistry and Technology., 2011, 9, 29 - 36.

\section{How to cite this article:}

Abdellaoui K Ratep, A, Boumaza A, Kashif I, Donya H.The effect of the natural raw barite and the dolomite material on borate glass formation. J. Fundam. Appl. Sci., 2018, 10(1), 281300 . 